\title{
PALM OLEIN LUBRICATES AND REMOVES FRESHLY BAKED CONCRETE FROM ITS FORMWORK
}

\section{SOH KHEANG LOH ${ }^{1 *}$ and NGATIMAN MUZZAMMIL ${ }^{1}$}

\begin{abstract}
Typical use of toxic and flammable petroleum-based mould oil for concrete manufacturing and its everincreasing price have prompted the search for a user-friendlier vegetable oil alternative. This study examines the potential use of a refined palm oil, i.e., palm olein for mould release lubrication. Its use eliminates additional steps required for structural modification and avoids food insecurity conflict due to its abundance and versatility. Blending palm olein (base oil) with a tackifier (specialty additive) was attempted to investigate their mould release characteristics. The concerned lubricating properties, i.e., viscosity index and flash point of the formulated mould oil were comparable to that of petroleum counterpart, while those distinguishable characteristics were saponifiable value, acid number and free fatty acid, which contributed to better mould release ability. The unmodified palm olein-based mould oil exhibited moderate level of oxidative stability with added advantages of non-corrosiveness and biodegradability. The optimised blend (90:10 of oil: additive) on trial could detach the moulded concrete from its formwork smoothly, showing good releasing ability desirable for concrete making.
\end{abstract}

Keywords: interfacial tension, mould release ability, palm olein, tackifier.

Received: 23 March 2021; Accepted: 15 July 2021; Published online: 28 September 2021.

\section{INTRODUCTION}

The global lubricant market has undergone dramatic changes due to overall flat demand, sharp shifts in consumption, increased competition and greater pressure on profits (Sahara Business Group, 2021). In 2019, the world demand for lubricants reached 36.8 million tonnes (Sönnichsen, 2021). While the growth in Asia Pacific and the Middle East was due to massive economic development and rise in the industrial sector, other mature markets, for example, the USA, Europe and Japan have remained flat since 1991 (Research and Markets, 2019; Theodori et al., 2004) due to stricter environmental regulations on lubricant use and disposal plus progressive introduction of synthetic oil with longer drain

1 Malaysian Palm Oil Board,

6 Persiaran Institusi, Bandar Baru Bangi,

43000 Kajang, Selangor, Malaysia.

* Corresponding author e-mail: lohsk@mpob.gov.my intervals. Many new lubricants are "filled for life" unlike their conventional counterparts, i.e., they can be recycled and reused while some of them are able to withstand long operation hours (EuropaLub, 2015). Although global share of vegetable oil-based lubricants or biolubricants market in the 1990s was very small, for example, only $2 \%$ was consumed in Europe from its total 10.2 million tonnes market (Rac and Vencl, 2008), the global demand is anticipated to grow at $\sim 7 \%$ annual rate to reach 1.12 million tonnes by 2024 in responding to various environmental issues associated with conventional lubricants (Grand View Research, 2016).

Biolubricants have gained much share nowadays for the desirable environmental features, for example, rapid biodegradability and low toxicity (Hassan et al., 2016) but their use is refrained by high cost (Ho et al., 2019). An ideal total replacement of conventional lubricants would only be anticipated industrially, if biolubricants could ever meet tough performance requirements and be low-cost (Woma 
et al., 2019). To date, biolubricants are about 1.5 to 5.0 times more expensive than the fossil-based counterparts (Srivastava and Sahai, 2013; Theodori et al., 2004). Price factor is indeed crucial for market penetration although other environmental factors are also important. Two significant market opportunities for biolubricants exist; sectors with high probability of accidental exposure of lubricant to sensitive environment and total loss of lubricants to the atmosphere, considering that they are low in ecotoxicity with high biodegradability (Mobarak et al., 2014; Srivastava and Sahai, 2013). Typical example of a total loss lubricant which ends up virtually entirely in the environment during normal use is mould release agent (Theodori et al., 2004). Its mould release ability is highly required when applied onto surfaces of building materials (such as concrete, steel, cement, etc.) during manufacturing.

The demand for building materials in construction industry is indeed huge due to vast development especially in developing and densely populated countries. In particular, during concrete block production, a mould release agent, normally fossil-based, is frequently used to perform lubrication during detachment of the moulded concrete from the formwork. Its use creates an unpleasant workplace and causes health problem, as it is flammable and toxic in nature (Libessart et al., 2014). The soaring fuel costs, plus an increased workers' awareness on healthy workplace have driven higher demand for environmental-friendly alternatives with better quality and regulatory conformity. Vegetable oilbased mould release lubricants stand a chance as they are not only non-toxic, renewable and biodegradable, also perform flexible surface activity and release ability dependent on polarity of the fatty acids present (Loh and Choo, 2012).

Mould release agents have been manufactured from mineral oils and waxes in the past with the incorporation of a chemically-active compound such as oleic acid to perform good release property. Others have co-existed with vegetable oil, aliphatic carboxylic acid ester, nonionic and anionic surfactant or antioxidant and polyacrylate forming oil-in-water emulsion (Nielsen, 1985; Wittich et al., 1995) to ease release of a moulded concrete piece from the mould. A more advanced mould oil was also developed using industrial wastes such as used cooking oil and engine oil (Yi, 1996). Non-refined vegetable oil such as coconut oil, corn oil, palm oil, cottonseed oil, rapeseed oil, soy oil and sunflower oil, either as a mixture or used individually with an emulsifier, to serve as a mould release agent with sealing effect to prevent the passage of water into the concrete (Lightcap, 1997). As a matter of fact, bio-based mould oils are less-performed than the fossil-based counterparts due to the feedstock natural characteristics. The inferior mould release property such as oxidation resistance, corrosion resistance, viscosity, tackiness, stability and antiwear can be overcome by incorporating properly designed specialty additives to suit for the intended use. Commercially available vegetable oil-based mould release agents mixed with oleic acid, alcohol and mineral seal oil (viscosity reducer) could reduce adhesion between concrete and formwork, thus, improving the life of the forms (LaFay and Neltner, 2002). The concrete-formwork lubricated with vegetable oil or mixed oil films shows overall satisfactory quality facings and release performance (Libessart et al., 2014). All the improved mould release agents invented so far exhibit a chemical rather than a barrier (physical) release. This means that vegetable oil-based mould release agents produce thin and harmless soap, up to double layers, between the concrete's surface and the mould itself in producing not just a smooth finish to the concrete but also a hydrophobic surface resistant to weather attack (Libessart et al., 2014). Their use ensures lesser volume consumed than the traditional agents, offers protection of steel mould casings from corrosion and extends formwork lifespan.

Issue on incidental contact of lubricant containing mineral oil saturated hydrocarbon (MOSH) and mineral oil aromatic hydrocarbon (MOAH) in crushing and refining plants during food processing has received much attention in the $21^{\text {st }}$ century due to an increased awareness and modernisation. Several requirements such as Hazard Analysis Critical Control Point (HACCP) and 'Makanan Selamat Tanggungjawab Industri' (MeSTI) certification schemes (KKM, 2018) have been implemented to monitor, certify and ensure food safety and hygiene for human consumption. Foodstuff can be unintentionally contaminated during transportation/ processing, via environmental sources, or through migration from food contact materials (Pirow et al., 2019). Mineral oilbased lubricants for food machinery uses will cause incidental food contact while those intended for external non-food applications include, for example, mould release agents, that will pose potential health risk to workers through inhalation exposure, in long run. Mineral oil-based release agents are also used in production processes, and thus, might as well cause food contamination. Human health threats such as toxicity and carcinogenicity (Pirow et al., 2019) due to exposure of mineral oil at a risky workplace, for example, concrete mould factory, has also triggered considerable attention worthy of investigation. Palm oil can be an alternative to provide high cleanliness and less dermatological problem at the workplace due to its promising skin compatibility (Dandan and Samion, 2017).

Undeniably, use of edible oil as lubricant, in general, faces pressure on food shortage crisis, food vs. fuel debate, energy security, and high oil price and dependence. In a global context, however, oil palm 
presents a huge opportunity via biotechnological advancement in terms of oil yield and productivity. To date, it is the highest world average oil bearing crop with yield at $\pm 3.5 \mathrm{t} \mathrm{ha}^{-1} \mathrm{yr}^{-1}$ (Singh et al., 2021) compared to other crops, such as rapeseed $(0.75$ $\left.\mathrm{t} \mathrm{ha}^{-1} \mathrm{yr}^{-1}\right)$, soybean $\left(0.56 \mathrm{tha}^{-1} \mathrm{yr}^{-1}\right)$ and coconut $(0.3$ $\mathrm{t} \mathrm{ha}^{-1} \mathrm{yr}^{-1}$ ) (Woittiez et al., 2017). This implies that oil palm is up to 10 times more productive per unit land area, and coupled with advanced and modern biotechnology approaches, shows evidence of future oil yield escalation and enhancement (Singh et al., 2021) to accommodate majorly food and sparsely (remaining) for non-food applications. Its high productivity ensures replenishable feedstock that will be able to meet the demand for vegetablebased lubricants in the future (Syahrullail et al., 2011). Relevant research literature on tribological performance has shown that vegetable oil-based lubricants are convincing to substitute mineral oils (Chan et al., 2018; Ho et al., 2019; Rao et al., 2018) with added environmental and social benefits. As such, the use of palm oil for non-food applications, i.e., biolubricant, as small as it seems, is aligned with the United Nations Sustainable Development Goals (SDG) No. 8, 9 and 12 in promoting productive employment and decent work, fostering innovation and ensuring sustainable production pattern. With an increased environmental concerns and technological advancement, the future of lubricant industry will shift towards producing highly specialised green lubricants from renewable sources such as vegetable oil, waste oil, animal fats and other biomass feedstocks (Shah et al., 2020). Next, many standard lubricants currently in use will be replaced with highly functionalised specialty counterparts, to be derived from tailor-made renewable resources, in addressing growing demand for ecotoxicological as well as sustainability criteria. This research contributes a small yet important aspect to the whole palm oil value chain in making the SDGs part of the industry's routine for a low-carbon green economy.

In the European Union, vegetable oil-based concrete release agents are usually based on rapeseed and soy oils and their esters (Theodori et al., 2004). Although vegetable oils are highly recommended, they have limited applicability as high-performance loss lubricant due to their inherently poorer lubrication properties (viscosity, thermal and oxidative stability and tackiness) compared to conventional or synthetic lubricants. The ability of pure vegetable oil to release a formed material under thermal stresses from its mould would be jeopardised, if it is not structurally modified or boosted with additives (Woma et al., 2019). Comparatively, the use of non-edible plant oils, such as Jatropha and Moringa oils (Souza et al., 2019) as pure and mixed blends (FarfanCabrera et al., 2020) or synthetic form (Pindit et al., 2021), can be considered but their availability is dependent on geographical locations and climate. Enzymatically and chemically catalysed high acid oil, a by-product of vegetable oil refining, such as soybean (Fernandes et al., 2021) and palm fatty acid distillates (Fernandes et al., 2018; Pindit et al., 2021), plus structurally modified used/waste cooking oil (Borugadda and Goud, 2016; Hussein et al., 2021; Owuna et al., 2020) are also exploited as sources of environmental-friendly biolubricants. Even residual oil such as those remaining in spent bleaching earth after oil refining can be of potential (Kheang et al., 2007; Sukirno and Farhandika, 2020). However, the production of these degraded waste oils, which have been loaded with impurities, into high-performance biolubricants will be costly as several steps such as pre-treatment, complex modification and posttreatment with specialty additives are required to improve their quality (Borugadda and Goud, 2016; Loh et al., 2006; Zhang et al., 2020). Furthermore, these oils are of limited supply and highly priced now as they are also much demanded as a biodiesel feedstock elsewhere (Argus Media, 2021). With inherently acceptable lubricity property and corrosion inhibition (Loh and Choo, 2012; Hassan et al., 2016), palm olein can be a potential readily usable base fluid alternative to petroleum for making into a mould release lubricant. Palm olein, the refined liquid product from crude palm oil (CPO), fulfilling the cleanliness criteria in base stock selection (Woma et al., 2019) with acceptable unsaturation level to resist oxidation (Loh and Choo, 2012) is thus, the right candidate amongst the ranges of palm oil products for mould oil formulation. Attempt was made to formulate a palm olein-based mould oil with an additive, benchmark its properties against the commercially used petroleum counterpart and evaluate its performance on-site intended for use in concrete manufacturing industry.

\section{MATERIALS AND METHODS}

\section{Materials}

Palm olein (iodine value $=56-58$ ) was obtained locally from a palm oil refinery, after undergoing refining, bleaching and deodourising (RBD) processes. RBD palm olein was chosen on the basis of its lubrication effect and fluidity for ready formulation with additive unlike $\mathrm{CPO}$, palm stearin (Afifah et al., 2019) or waste cooking oil (Borugadda and Goud, 2016) which is deemed unsuitable before used due to physical appearance and quality issue. The specialty additive used, a National Sanitation Foundation (NSF)-certified ingredient for use in lubricants with incidental food contact (HX-1), i.e., a food-grade tackifier (Functional-V584, Reg. No. 120913) (specific gravity $=0.93$, flash point $=150^{\circ} \mathrm{C}$, thickening efficiency $=55-70 \mathrm{cSt} @ 40^{\circ} \mathrm{C}$ ), was 
purchased commercially from Eweka International (Singapore) Pte. Ltd. The chosen NSF-certified tackifier at a permissible $\pm 10 \mathrm{vol} . \%$ is considered safe for workers in case of any incidental contact in and around the workplace. The petroleumbased mould oil in use by the collaborator in this study, a local manufacturer of concrete blocks as construction materials, has specifications as stipulated in Table 1. These specifications were referenced against the lubricating properties of the optimum blend of palm olein-based mould oil formulated in this study.

\section{Methods}

Viscosity and its relationship with temperature and pressure primarily affect the tribological performance of a lubricant (Chan et al., 2018). In this study, palm olein was dosed with the tackifier, Functional-V584 to improve its viscosity desirable for mould oil formulation. No chemical/structural modification was required. Five different palm olein: tackifier ratios, i.e., 95:5, 90:10, 85:15, 80:20 and 75:25 $(\mathrm{v} / \mathrm{v} \%)$ were used for optimisation study, in order to obtain a suitable blend with the targeted viscosity. Laboratory-scale optimisation was conducted by formulating five different blends of palm oleinbased mould oil according to the above-mentioned palm olein: tackifier ratios using $250 \mathrm{ml}$ beakers, followed by screening of the resulting kinematic viscosity of the blends. No software was used for the optimisation study. The ingredients were mixed and stirred vigorously at $100 \mathrm{rpm}$ while keeping temperature between $50^{\circ} \mathrm{C}$ to $60^{\circ} \mathrm{C}$ for $30 \mathrm{~min}$, and then stored in sealed amber glass bottles prior to kinematic viscosity analysis. The optimum ratio that gave as close to the kinematic viscosity of the petroleum counterpart as possible was screened and identified by withdrawing a small sample aliquot from each blend $(20 \mathrm{ml})$ for the kinematic viscosity analysis. No further correlation was conducted on physical properties, friction and wear, etc. for all the blends at this stage. Once the optimum blend was identified, large-scale mould oil production was conducted for field evaluation. A fabricated 200-litre mild steel mixer tank (Figure 1) equipped with an agitator motor $(0.4 \mathrm{~kW} / 415 \mathrm{~V})$, a heater and a programmable logic controller was designed and used to produce the intended mould oil based on the optimised palm olein: tackifier (90:10) blend. Both palm olein (180 litre) and tackifier, Functional-V584 (20 litre) were poured into the mixer tank. The tank was agitated and heated from room temperature to $60^{\circ} \mathrm{C}$ and maintained for $30 \mathrm{~min}$ to ensure complete mixing of the two ingredients. The homogenous solution was cooled to room temperature prior to storage for field trial. Palm olein: tackifier (100:0) and (95:5) blends were used as controls.

TABLE 1. LUBRICATING PROPERTIES OF PALM OLEIN, PALM OLEIN-BASED MOULD OIL AND COMMERCIAL MOULD OIL

\begin{tabular}{|c|c|c|c|}
\hline Property & $\begin{array}{l}\text { Palm olein } \\
\text { (pure blend) }\end{array}$ & $\begin{array}{l}\text { Palm olein-based } \\
\text { mould oil; palm olein: } \\
\text { additive }(90: 10)^{\mathrm{b}}\end{array}$ & $\begin{array}{c}\text { Commercial } \\
\text { mould oil }\end{array}$ \\
\hline Density at $25^{\circ} \mathrm{C}\left(\mathrm{kg}\right.$ litre $\left.{ }^{-1}\right)$, ASTM-D4052 & 0.8975 & 0.9090 & 0.8838 \\
\hline Viscosity, kinematic @ 40 $\mathrm{C} / 100^{\circ} \mathrm{C}$ (cSt), ASTM D445 & $41.66 / 8.47$ & $58.42 / 11.29$ & $107.52 / 18.76$ \\
\hline Viscosity index, ASTM D2270 & 186 & 191 & 195 \\
\hline Moisture content (\%), ASTM D1744 & 0.056 & 0.5095 & 0.072 \\
\hline Saponifiable value (mg KOH g-1 oil), MPOB c2.9:2004 & 192 & - & NA \\
\hline Pour point $\left({ }^{\circ} \mathrm{C}\right)$, ASTM D97 & 6.0 & 6.0 & -3.0 \\
\hline Cloud point $\left({ }^{\circ} \mathrm{C}\right)$, ASTM D2500 & 7.0 & 9.4 & -5.2 \\
\hline Total acid number $\left(\mathrm{mg} \mathrm{g}^{-1}\right)$, ASTM D664 & 4.60 & 0.8 & 3.92 \\
\hline Free fatty acids (\%), MPOB c2.5:2004 & 0.079 & 0.76 & NA \\
\hline Copper strip corrosion, ASTM D130 & $1 \mathrm{a}$ & $1 \mathrm{a}$ & $1 \mathrm{a}$ \\
\hline Oxidative stability (hr), EN 14112 & 25.30 & 22.83 & NA \\
\hline Oxidative stability by RPVOT (min), ASTM D2272 & 14 & 72 & NA \\
\hline Flash point $\left({ }^{\circ} \mathrm{C}\right)$, ASTM D93 & 305 & 340 & 246 \\
\hline Biodegradability @ 28 days incubation, OECD 301F & - & $>60 \%$ (readily biodegradable) ${ }^{c}$ & NA \\
\hline
\end{tabular}

Note: ${ }^{a}$ Means reported, $\mathrm{n}=2 ;{ }^{\mathrm{b}}$ Loh et al. (2010). The characteristics are typical of this batch production. Future product will conform to this specification, in which variations in the characteristics may occur; ' Siti Afida et al. (2015); ASTM - ASTM International, formerly known as American Society for Testing and Materials; MPOB - Malaysian Palm Oil Board; KOH - potassium hydroxide; RPVOT - rotating pressure vessel oxidative test, OECD - Organisation for Economic Co-operation and Development; NA - not applicable. 

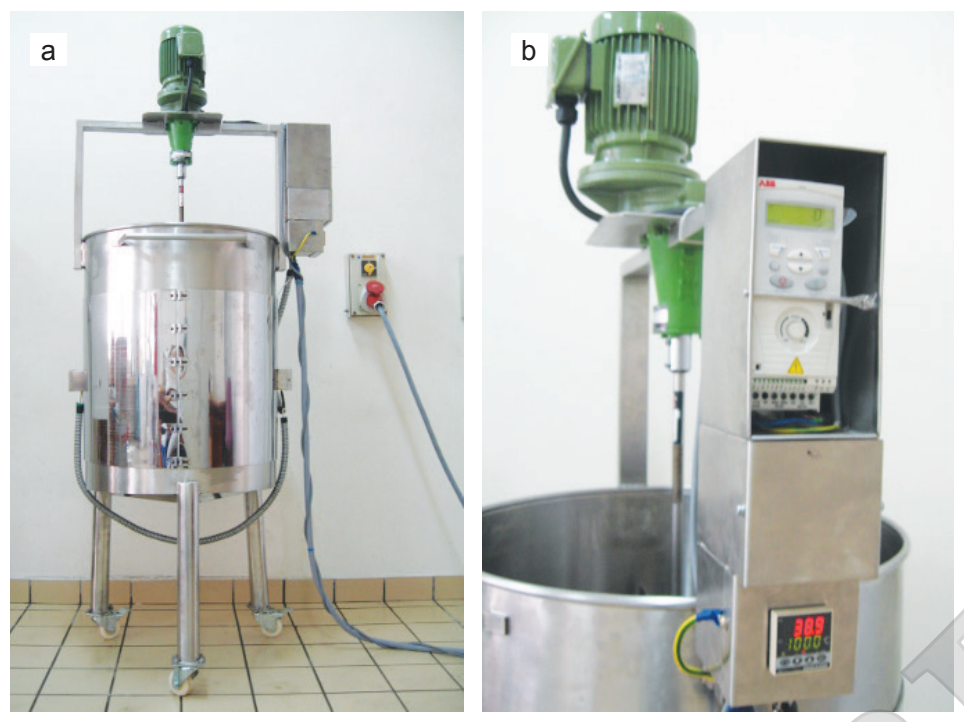

Figure 1. A 200-litre capacity mixer tank (a) front view, and (b) back view for blending of palm olein-based mould oil.

\section{Analyses}

The lubricating characteristics of palm olein and its optimum mould oil blend were measured according to standard test methods. Kinematic viscosity of the oil samples $(20 \mathrm{~g})$ at $40^{\circ} \mathrm{C}$ and $100^{\circ} \mathrm{C}$ was simultaneously measured by a dualbath automated multi-range viscometer HVM472 (Walter Herzog, Germany) according to ASTM D445. Viscosity index was calculated based on ASTM D2270 from the resulted kinematic viscosities at $40^{\circ} \mathrm{C}$ and $100^{\circ} \mathrm{C}$. Density was measured according to ASTM D4052 by a Mettler-Toledo digital density meter DE40 at $25^{\circ} \mathrm{C}$. Pour point and cloud point were measured by an automatic pour point/cloud point measuring apparatus (ISL CPP 97-2 Analyser) based on ASTM D97 and ASTM D2500, respectively while flash point measurement by a Pensky-Martens closed cup tester, ASTM D93 using an automated flash point tester (Petrotest, Germany). Moisture content was measured via the Karl Fisher method, ASTM D1744. Oxidative stability was determined via rotating pressure vessel oxidative test (RPVOT) using a quantum oxidation tester (Tannas, USA) according to ASTM D2272. Oil sample (50 g), water $(5 \mathrm{ml})$ and a copper catalyst coil were placed in a stainless-steel pressure chamber which spun at a $30^{\circ}$ angle, $100 \mathrm{rpm}$ at $150^{\circ} \mathrm{C}$ with $\mathrm{O}_{2}$ supplied at 90 psi. The oxidation time of the test oil was determined when there was a drop of pressure of $25.4 \mathrm{psi}$ in the chamber. Copper strip corrosion was performed on a Petrotest test bath (Germany) for $3 \mathrm{hr}$ at $50^{\circ} \mathrm{C}$, ASTM $\mathrm{D} 130$. The corrosion level was reported by comparing the tested copper strips with the standard. Total acid number was determined via potentiometric titration using Metrohm titrator based on ASTM D664. Free fatty acid (FFA) was measured using titration method according to MPOB Test Methods c2.5: 2004 (MPOB,
2005). Mixture of oil (20 g), neutralised iso-propanol $(50 \mathrm{ml})$ and phenolphthalein indicator solution $(2 \mathrm{ml})$ was stirred and heated on a hot plate at $40^{\circ} \mathrm{C}$ in a 100-ml conical flask. Sodium hydroxide, $0.1 \mathrm{M}$, was titrated to the mixture, to a persistent permanent pink colour. The FFA content was calculated based on the percentage of palmitic acid. Saponifiable value (SV) was determined based on MPOB Test Methods c2.8: 2004 (MPOB, 2005). Mixture of oil $(5 \mathrm{~g})$ and ethanolic potassium hydroxide solution (50 $\mathrm{ml}$ ) was boiled under reflux, then phenolphthalein indicator $(1 \mathrm{ml})$ was added followed by titrating the excess potassium hydroxide with $0.5 \mathrm{M}$ hydrochloric acid solution, to total disappearance of pink colour. The biodegradability of the optimum mould oil blend was tested for a 28-day incubation period based on Organisation for Economic Co-operation and Development (OECD) Test Guideline 301F Manometric Respirometry Test using the BOD EVO system (Velp, Italy). The procedure of the test and the method to calculate the biodegradability percentage can be referred to in Siti Afida et al. (2015). All determinations were performed in duplicate, and the mean values were reported. As a cost-savings measure, the lubricating properties of the rest of the formulated blends of palm oleinbased mould oil in this study were not analysed except kinematic viscosity for optimum mould oil blend identification based on the guiding principle that it must exhibit the closet kinematic viscosity to that of the commercial counterpart.

In addition, oxidative stability via the Rancimat method was measured using a Model 743 Rancimat instrument (Metrohm AG, Switzerland). Oil sample $(3 \mathrm{~g})$ was analysed under a constant airflow of 10 litre $\mathrm{hr}^{-1}$ at $110^{\circ} \mathrm{C}$ heating temperature. The fatty acid compositions (FAC) of the samples were determined according to ISO 5508: Animal and vegetable fat 
and oil analysis by gas-liquid chromatography. The measured FAC could be used to indicate and support the stability and cold flow property of the formulated mould oil. Analysis was carried out using a Hewlett Packard 5890 Series II gas chromatograph equipped with a flame ionisation detector and a split injector. A fused silica capillary column $(60 \mathrm{~m} \times 0.25 \mathrm{~mm})$ coated with a highly polar stationary phase, Supelco SP2340 $(0.2 \mu \mathrm{m})$, was used with a programmed temperature profile as follows: oven temperature, $185^{\circ} \mathrm{C}$; injector temperature, $240^{\circ} \mathrm{C}$; detector temperature, $240^{\circ} \mathrm{C}$; split ratio, 1:100; and carrier gas, helium at $2.0 \mathrm{ml} \mathrm{min}^{-1}$. All determinations were performed in duplicate and only the means were reported.

\section{Field Evaluation}

The produced palm olein-based mould oil (100 litre) was stored in drum and sent immediately to the collaborator's concrete manufacturing site for trials. The required conditions for commercial concrete production were: 1.5 litre mould oil per formwork; oven baking (moulding) temperature, $80^{\circ} \mathrm{C}$ and baking (drying) time, $3.5 \mathrm{hr}$; autoclave curing temperature and time, $190^{\circ} \mathrm{C}$ and $7 \mathrm{hr}$, respectively. Ten consecutive formworks were operated in parallel during the trial. Figure 2 illustrates the process flow during mould oil trial for concrete manufacturing at the production line. The mould oil was applied thoroughly to the inner walls of the formwork using a roller to form a thin oil film and any oil surplus was removed prior to pouring concrete mixer onto the formwork via a nozzle installed at the top until it was half filled. Since the concrete mixer was pushed down forcefully by gravity due to the height of the nozzle, mould oil with sufficient tackiness is required so that it will not be squeezed out leaving the formwork unlubricated. The concrete mixer slowly solidified upon completion of pouring. The moulded concrete was baked in an oven at $80^{\circ} \mathrm{C}$ $\pm 2^{\circ} \mathrm{C}$, then cured in an autoclave at $190^{\circ} \mathrm{C} \pm 5^{\circ} \mathrm{C}$ for $7 \mathrm{hr}$ and cooled before the hardened concrete was detached from the formwork by turning the formwork upside down and unscrewed it. Visual observation was performed on the detached finished goods and the formwork. Field trial evaluation was performed on selected blends (palm olein: tackifier $=100: 0,95: 5,90: 10 \mathrm{v} / \mathrm{v} \%$ ).

\section{RESULTS AND DISCUSSION}

In commercial concrete block production, a lubricant with desirable mould release property is particularly useful to facilitate process of detaching the moulded concrete from its formwork. The commonly used petroleum-based mould release agent (Table 1)

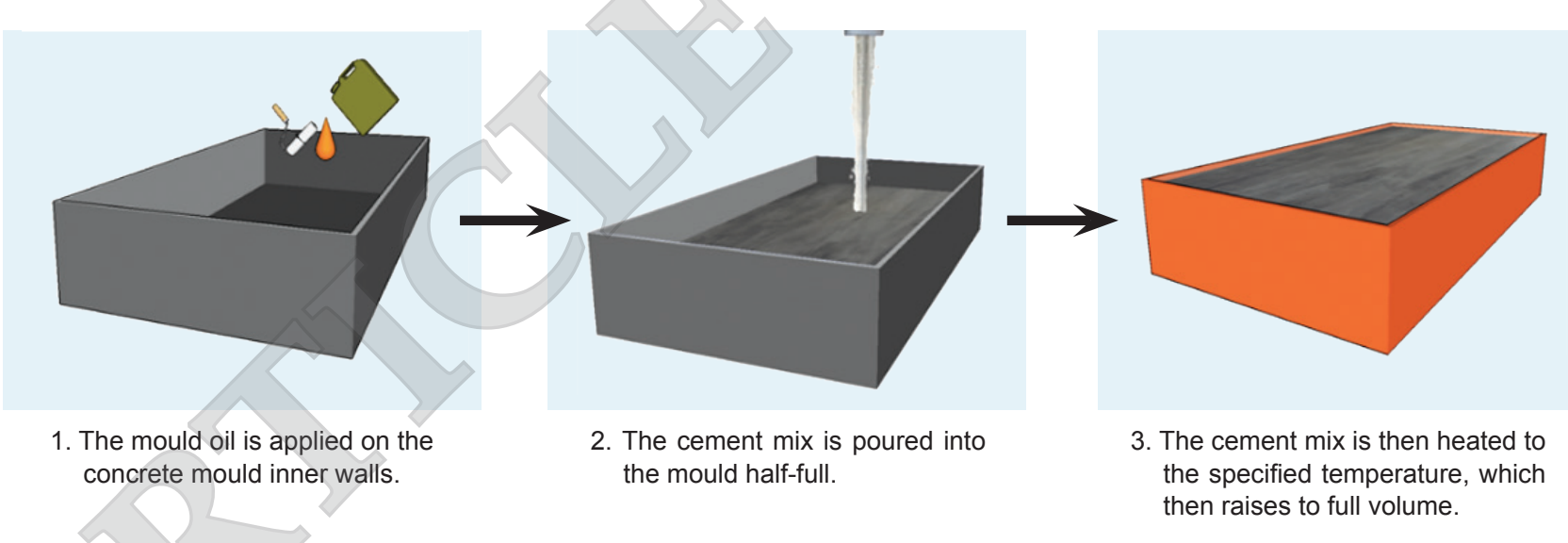

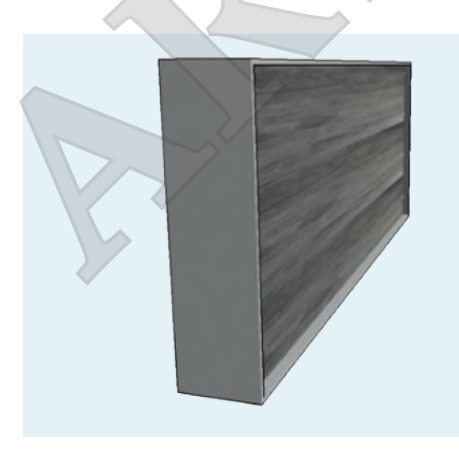

4. Once hardened, the mould is tilted to the side.

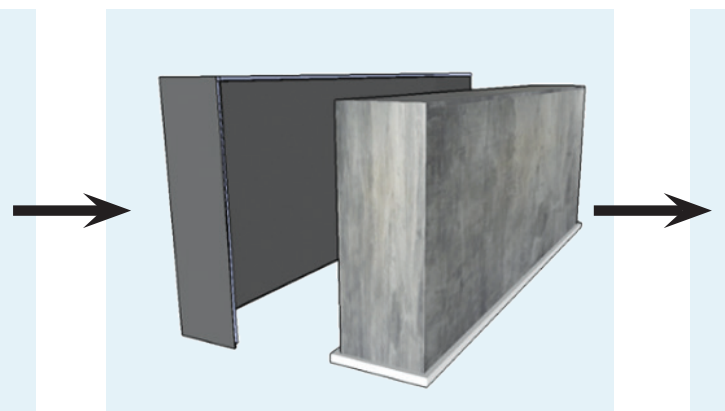

5. Slowly the mould will be detached from its container and formed product sent for autoclave process.

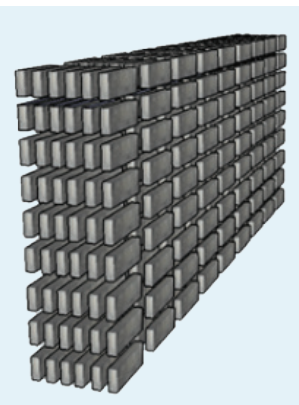

6. Once the treatment is done and before drying, the formed mould is cut into desired dimensions. 
exhibits chemical rather than a barrier (physical) release, lubricates and produces a smooth finish to the concrete, ensures less volume of lubricant used and protects mould casings from corrosion. It has high kinematic viscosity of $107.5 \mathrm{cSt}$ at $40^{\circ} \mathrm{C}$ and passes the copper strip corrosion test (ASTM D130). For the intended concrete blocks manufacturing, it is desirable to have a good mould release agent in fulfilling the three important characteristics, i.e., lubricity, release ability and corrosion protection. Theoretically, in palm olein-based mould oil formulation, these important lubricating properties, in particular kinematic viscosity, must be met in order to yield a comparable product. Palm olein with a kinematic viscosity of $41.7 \mathrm{cSt}$ at $40^{\circ} \mathrm{C}$ can be enhanced using a tackifier. Although the kinematic viscosity of the formulated palm olein-based mould oil increased steadily (Figure 3) with increasing doses of tackifier, it was impractical and costly to use a high dose of 25 vol.\% which could increase the kinematic viscosity to the desired $109 \mathrm{cSt}$ at $40^{\circ} \mathrm{C}$ comparable to the petroleum counterpart. As the attempt was to formulate an eco-friendly mould oil, the maximum dose could only be up to \pm 10 vol. $\%$ for any incidental contact during manufacturing. As such, 10 vol.\% of tackifier was used in the palm olein-based mould oil formulation yielding just a half of the desired kinematic viscosity of 58.42 cSt without jeopardising its mould release performance as shown in the field trials conducted. The naturally inherited characteristics of palm olein as discussed in Loh and Choo (2012) and further elaborated in this study are capable of maintaining the lubricating properties required similar to the used petroleum counterpart, and for a reduced cost measure as well.

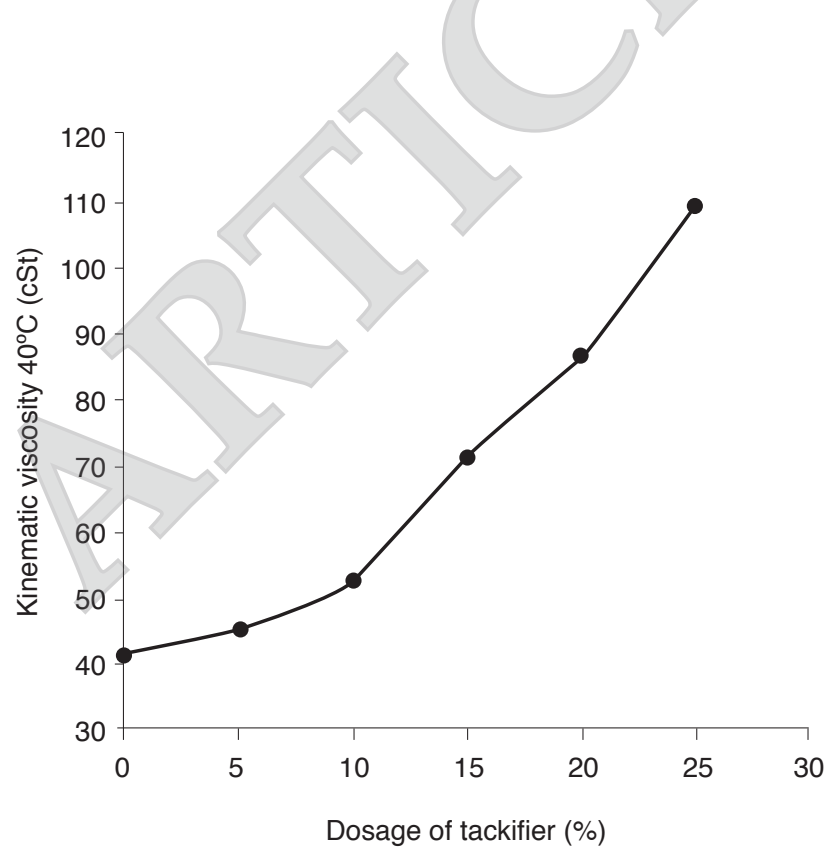

Figure 3. Influence of tackifier on kinematic viscosity of the palm oleinbased mould oil (single measurement).

\section{Characteristics of Palm Olein-based Mould Oil}

The newly formulated palm olein-based mould oil (Figure 4) at an optimum 90:10 palm olein (as a base fluid): tackifier blend was characterised. Table 1 shows that the formulated mould oil had lubrication properties comparable to the petroleum-based commercial counterpart. Although palm olein was less viscous and could not meet the commercial specification of $\sim 108 \mathrm{cSt}$, it could outperform in other aspects once a tackifier was added. In reality, additives are essential in almost any lubricants tailored to enhance key performance attributes. The formulated palm olein-based mould oil showed a moderate kinematic viscosity $\left(58.42 \mathrm{cSt} @ 40^{\circ} \mathrm{C}\right.$ and 11.29 cSt @ $100^{\circ} \mathrm{C}$ ) and a high viscosity index (191) which indicated good lubricity for the intended use. The oil was anticipated to experience very little viscosity changes with temperature effect owing to its high viscosity index. Its density was comparable to the benchmarked commercial mould oil but the moisture of $0.51 \%$ could imply that the oil might be prone to chemical decomposition known to affect its hydrolytic stability. The oil passed the copper strip corrosion test (1a), implying a non-corrosive substance used, as was evidenced by the low acid number of $0.8 \mathrm{mg} \mathrm{KOH} \mathrm{g}^{-1}$ (Table 1).

The induction period $(22.8 \mathrm{hr})$ via Rancimat test ensured that the formulation was stable and could withstand oxidation. The RPVOT time (14 min) of palm olein had been increased to $72 \mathrm{~min}$ after the formulation (Table 1). The RPVOT stability of the formulated palm olein-based mould oil was considered moderately well compared to those of soy-based chainsaw bar oil, 83 min (Cermak et al., 2008); chemically modified castor-based lubricants,

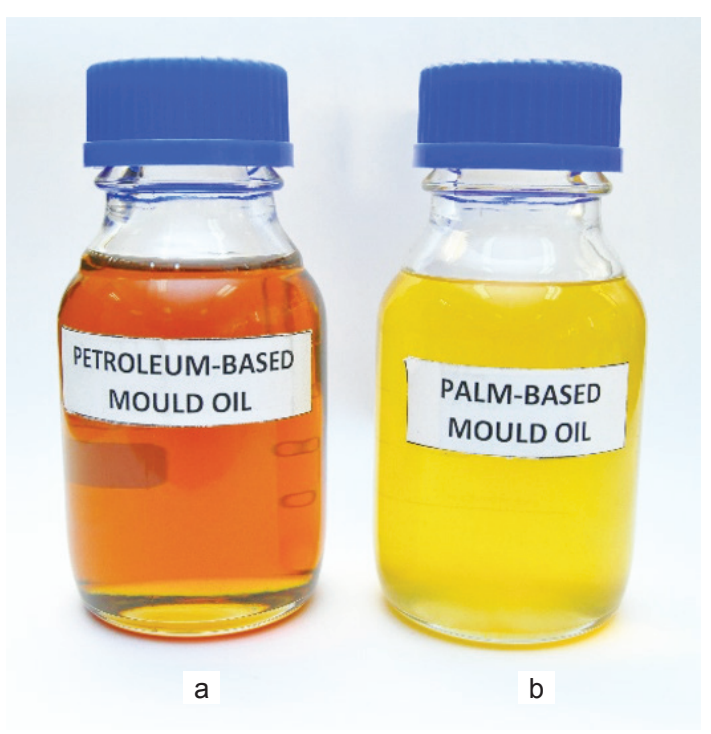

Source: Loh et al. (2010).

Figure 4. (a) Commercially used petroleum counterpart vs. (b) palm olein-based mould oil formulated. 
43-150 min (Annisa and Widayat, 2018) and coconut oil-based estolites, 100-326 min (Cermak et al., 2008), the latter two of which boosted with varying antioxidants. All vegetable oils without antioxidants have RPVOT times $<20$ min (Cermak et al., 2008). The value is indicative of good degree of free-radicals (chemical) resistance, showing low oxidation tendency which reassures longer remaining useful life of the in-service oil. The oxidative stability of the above-mentioned plant oils, having either $>90 \%$ unsaturation (soy and castor) or saturation (coconut) level, has been greatly improved via oligomerisation / esterification while the palm olein in this study can be used without chemical modification due to its appropriate saturated/unsaturated content to maintain a satisfactory oxidative stability. The major cause of poor oxidative stability of vegetable oil is FAC. According to Owuna et al. (2020), the fatty acids (unsaturation) present influences the thermal and oxidative stability of the formulated vegetable oil-based lubricant. Double bonds are susceptible to oxidation forming a series of corrosive oxygenated compounds. An oxidation-resistant lubricant will have fewer tendencies to form deposits, sludge and corrosive by-products during application. When oil is oxidised, it tends to thicken and polymerise and its functions degrade over time (Owuna et al., 2020). In this study, the FAC profile (Table 2) of the formulated mould oil showed almost equal 45 saturated (C12, C14, C16, C18):54 unsaturated fatty acids (C18:1, C18:2, C18:3) level. This had rendered a fairly good oxidative stability of the mould oil, however, its cold flow properties, i.e., pour point and cloud points might be compromised. It might not be suitable for use in cold environment and handling will be issue too. Formed wax crystals might clog filters and plug / openings leaving deposits on surfaces. Nevertheless, wax formation will not be encountered using palm oil in tropical climate (Liang et al., 2016). The mobility and intermolecular interactions of oil molecules are restricted as temperature decreases due largely to crystalline molecular packing, which facilitates interlocking of the sharp needle-like triacylglycerol crystals. Although soybean, sunflower and rapeseed oils with $>80 \%$ unsaturation (Table 2) show excellent cold flow properties (Quinchia et al., 2012), they are more susceptible to oxidation. As palm olein exhibits iodine value of 57 (average) which falls within but at the lower end of the acceptable range (i.e., 50 to 130) for biolubricants formulation, its ability to flow at low temperature is not as easy as in tropical climate. However, this range of iodine value has positively impacted the mould release capability during field trial where the moderate level of $C=C$ double bonds present does not show much affinity in attracting metallic cationic molecules due to relatively lower level of $\pi$-bond reactivity. The ester linkages (Figure 5) provide a vulnerable site for microbial cells to initiate the biodegradation process of the ester-derived triacylglycerol fat molecules (Siti Afida et al., 2015), which translates into very high biodegradability rates for ester-based biolubricants. Being renewable with high degree of biodegradability (Table 1), palm olein is therefore environmental-friendly and suitably used as a loss lubricant as any vapour generated and emitted during lubrication process will be non-toxic to the atmosphere.

\section{Influence of Palm-based Mould Oil at Concrete- Formwork Interface}

Palm olein with inherent lubricity property and corrosion inhibition capability (Loh and Choo, 2012; Hassan et al., 2016), as shown in Table 1, is a potential alternative to petroleum-based or synthetic mould oil used in current concrete manufacturing workplace. It is found effective in preventing concrete adhesion to aluminum (Freedman, 1975) and other metals. As palm olein is naturally polar due to the bound fatty acids in the triglyceride backbone, it has strong adhesion to and high affinity

TABLE 2. COMPARISON OF FATTY ACID COMPOSITIONS (FAC) OF PALM OLEIN WITH OTHER VEGETABLE OIL

\begin{tabular}{|c|c|c|c|c|c|}
\hline \multirow{2}{*}{$\begin{array}{l}\text { FAC } \\
(w t . \%)\end{array}$} & \multirow{2}{*}{$\begin{array}{l}\text { Palm olein } \\
\text { (pure blend) }^{\mathrm{a}}\end{array}$} & \multirow{2}{*}{$\begin{array}{l}\text { Palm olein-based mould oil }{ }^{a} \\
\text { Palm olein: additive }(90: 10)\end{array}$} & \multirow[t]{2}{*}{ Soybean oil } & Rapeseed oil & Sunflower oil \\
\hline & & & & \multicolumn{2}{|c|}{ (Quinchia et al., 2012) } \\
\hline Lauric acid (C12:0) & 0.3 & - & - & - & - \\
\hline Myristic acid (C14:0) & 1.0 & 1.14 & - & - & - \\
\hline Palmitic acid (C16:0) & 39.8 & 40.06 & 11.28 & 4.56 & 6.18 \\
\hline Stearic acid (C18:0) & 4.4 & 3.62 & 2.70 & - & 2.16 \\
\hline Oleic acid (C18:1) & 42.4 & 43.77 & 24.39 & 65.99 & 26.13 \\
\hline Linoleic acid (C18:2) & 12.2 & 10.73 & 56.28 & 21.13 & 65.52 \\
\hline Linolenic acid (C18:3) & 0.4 & 0.68 & 5.34 & 8.16 & - \\
\hline Arachidic acid (C20:0) & 0.4 & - & - & - & - \\
\hline
\end{tabular}

Note: ${ }^{a}$ Means reported, $\mathrm{n}=2$. 
for metal surfaces, i.e., the wall of the formwork (Figure 5). This could help in maintaining a thin film over the oil-formwork interface and therefore provides an improved lubricity (Gawrilow, 2003). With such inherent properties, palm olein presents more advantageous as a mould release lubricant than its petroleum counterparts.

Besides, palm olein with SV of 186-198 mg $\mathrm{KOH} \mathrm{g}^{-1}$ oil is desirable to perform mould release characteristic (Gawrilow, 2003). SV indicates the degree of a lipid in undergoing hydrolysis under basic condition to form a soap. Owing to naturally occurring triglyceride-based fatty acids, this range of SV tends to facilitate metal soap formation between oil (esters) molecules and the alkaline concrete aggregates (containing metal ions). In general, acceptable SV of plant oils is ranged 176$244 \mathrm{mg} \mathrm{KOH} \mathrm{g}^{-1}$ oil (Gnanasekaran and Chavidi, 2018; Joseph and Saxena, 2017). A higher SV range is undesirable as it mobilises the concrete particles within the oil-formwork interface, thus softening takes place resulted in concrete sticking on formwork and striping is difficult (Bouharoun et al., 2012, Freedman, 1975). The saponification ability of a vegetable esters in forming soap layers at the formwork interface is an added advantage for surface release lubrication, as oil participates in the formation of interstitial mediums creating a stable emulsion in the vicinity of formwork (Bouharoun, 2016).

In a similar manner, as the palm olein-based mould release agent formulated has naturally inherited fatty acids as a foreign (added) acidifier, as opposed to the petroleum counterparts, it shows a reduction in friction, i.e., better release of mould and a high resistance to charge transfer. The presence of incoming fatty acids (surface active additive) is anticipated to catalyse greater soap formation (with basic charged metal ions), leading to a specific interface orientation of esters and fatty acid molecules in layers. The existence of different forms and strength of functional linkages due to different degrees of polarity between the oil and fatty acids has resulted in higher tendency of the latter to compete and orient preferentially as soap film in the concrete-oil-formwork interface (Figure 6), where chemical effect has taken precedence over the physical effect. As a result, it reduces and relaxes the interfacial tension (Djelal et al., 2008), and hence enabling mould release ability and performance. This characteristic has greatly succeeded in overcoming major shortcoming of palm olein-based mould oil deployment considering its borderline kinematic viscosity for the intended commercial application.

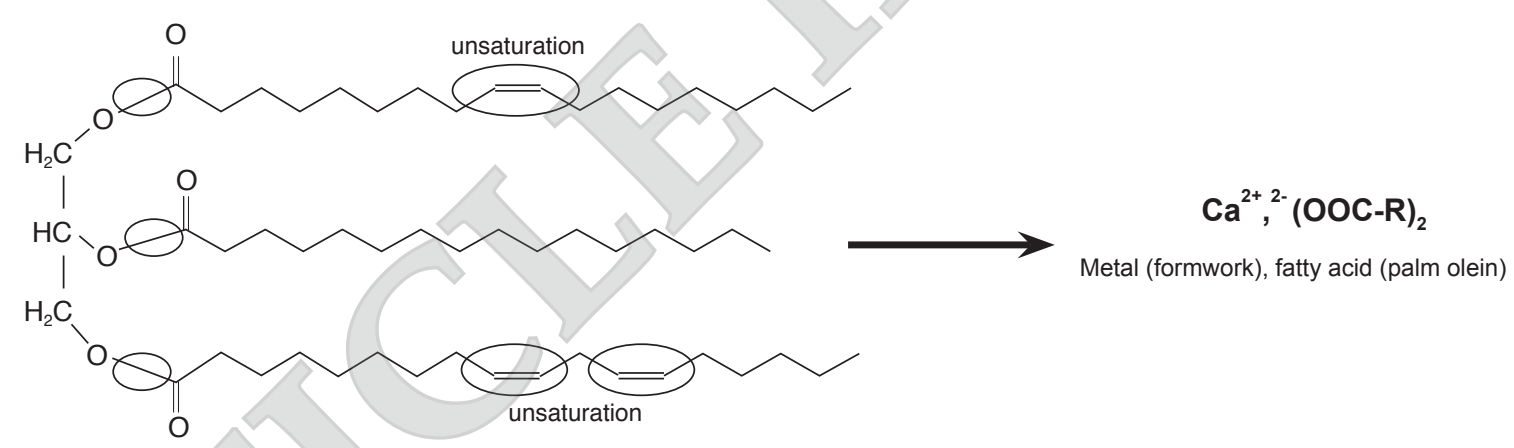

Figure 5. Interaction of a fatty acid or ester bound vegetable oil (left) with the metal surface of a formwork in performing a release property.

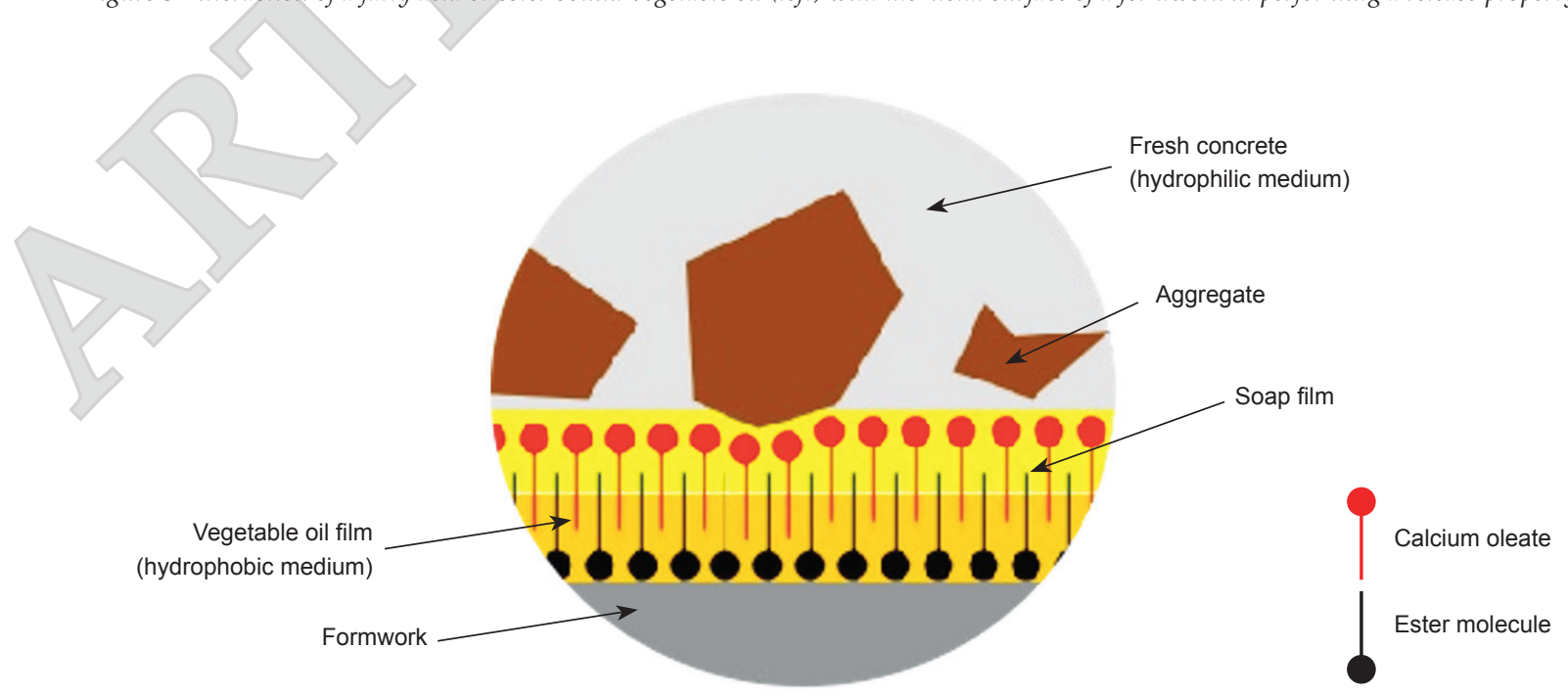

Figure 6. Organisation of a soap film at the concrete-oil-formwork interface (adopted from Bouharoun et al., 2012). 


\section{Performance Evaluation}

The performance of a mould oil is indicated by the condition of the moulded concrete after being detached from its formwork. The method of applying mould oil on the wall formwork is particularly important as evenly and thinly distributed oil conditions the quality of the concrete facing. The mould oil, when applying evenly to a clean surface, creates a continuous and uniform film. On the contrary, untouched wall will form bonding to concrete products being made.

Besides having a minimal viscosity range desirable for concrete working conditions, the palm olein-based mould oil is capable of remaining in place to perform the required lubricity and mould release property within the concrete-oilformwork interfaces. As the naturally-occurring and polarised ester linkage in palm oil imparts good lubricity (Gawrilow, 2003; Loh and Choo, 2012), it can withstand friction stress or pushing forces (Hassan et al., 2016) incurred during pouring of the concrete onto the formwork. Hence, it provides and maintains a thin and continuous film over the oil-formwork interface, to smoothen, lubricate and release the moulded concrete easily. An overdosing or excess oil on the formwork causes poor concrete facing quality as it gives rise to softening and uncooked concrete blocks with obvious oil stain. The deriving low acid number of $0.8 \mathrm{mg} \mathrm{KOH} \mathrm{g}^{-1}$ (Table 1) implies less corrosive properties (Owuna et al., 2020) and hydrolysis of esters in water, if any, while performing the desired mould release.

The field trials of the selective mould oil blends at palm olein: tackifier 100:0, 95:5, 90:10 (v/v\%) were evaluated on-site at a concrete production factory. The resulted concrete blocks using $100 \%$ palm olein blend (negative control) showed inferior quality with noticeable soft concrete surfaces that retained the mould oil as oil dots on the surfaces of the blocks (bottom and both ends of the block) (Figure 7a). The oil dot area was obviously not cooked and soft with a depth of approximately $3-5 \mathrm{~mm}$. As a pure blend, it was less viscous (42 cSt) compared to palm olein-based (58 cSt) and petroleum-based mould oil (108 cSt), hence some of the concrete surfaces were not fully covered and lubricated, causing surfaces deterioration or damage and softness. Accepting the fact that almost all formulated lubricant systems in the market require additives to be on par for high performance compatibility, a tackifier is undoubtedly needed to increase the viscosity inadequately performed by palm olein which subsequently enhance the mould release property. However, by adding 5 vol.\% of the tackifier into palm olein, the resulted finished products failed to

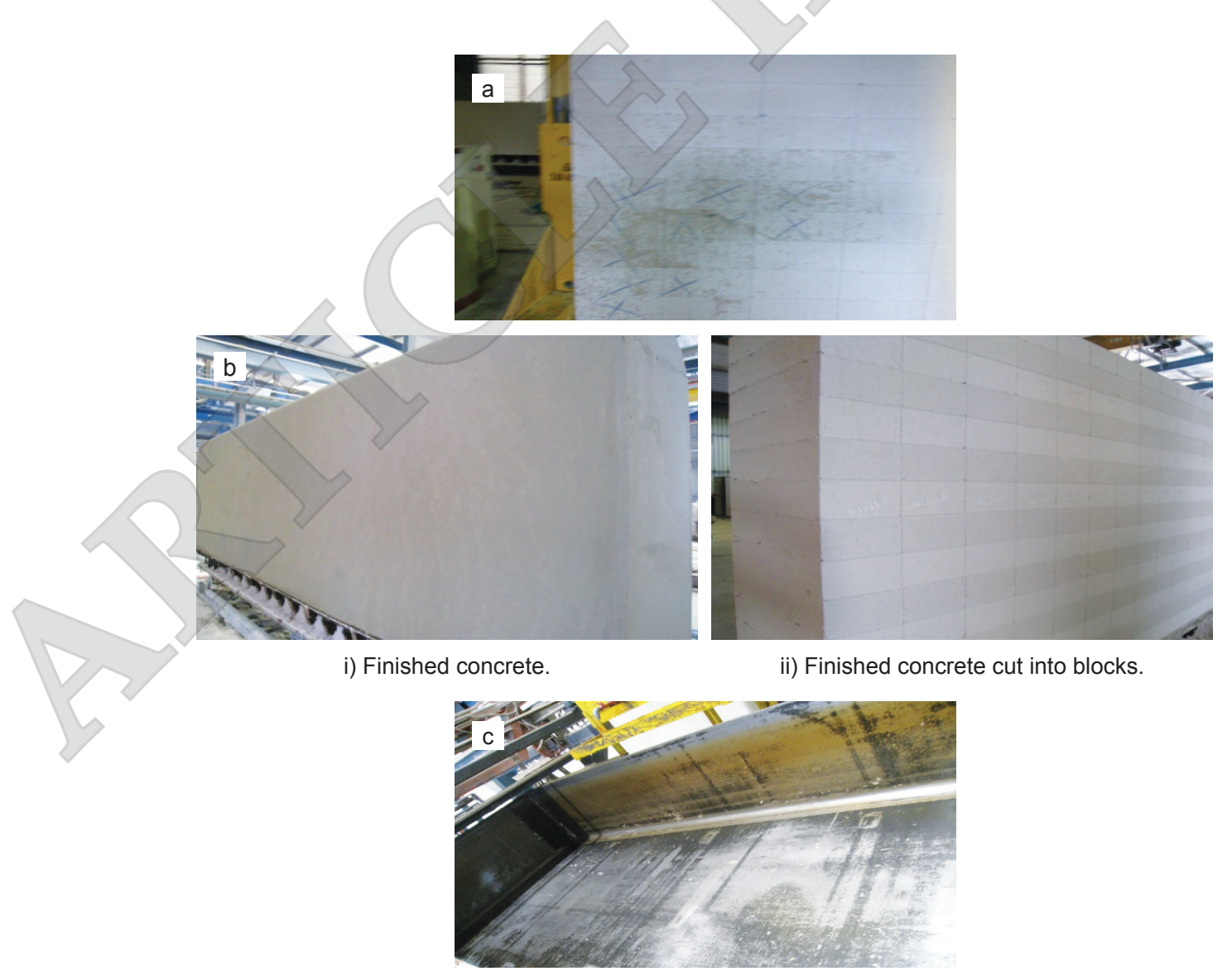

Figure 7. Mould oil performance on finished concrete blocks (a) oil stain (visibly darker), (b) clean surface and (c) no concrete leftover sticking in the inner wall or surface of the mould car. 
show any improvement. Lastly, the prior identified 90:10 palm olein: tackifier optimum blend (based on kinematic viscosity) showed very promising results. The finished concrete blocks showed no oil stain on concrete surfaces (Figure $7 b$ ) and no breakage (broken edges or broken corners) during cake demoulding; and the formwork showed smooth surfaces without cement sticking onto the sides and bottom (Figure 7c). As mentioned earlier, relatively, though ester-based biolubricants might be more susceptible to hydrolytic attack and prone to issue on material-lubricant compatibility (Ho et al., 2019), the performance of the respective palm oleinderived mould release agent was not affected even in the presence of water in the concrete mixer.

The potential of palm olein as a base stock for mould oil formulation was evident from the findings of the field trials conducted in this study as concluded based on visual observation and assessment. In this study, temperature range for concrete moulding process was $80^{\circ} \mathrm{C}$ (baking) and $190^{\circ} \mathrm{C}$ (curing) to shape and harden the formed concrete. The formulated mould oil has a flash point, $340^{\circ} \mathrm{C}$, much higher than the moulding temperature, so there will be no flammability issue as the temperature experienced will not be able to vapourise the oil to form an ignitable mixture. The resulting low volatility will not pose fire hazard at workplace and can prolong its use as a total loss lubricant. The tribological and rheological behaviour and many other physical aspects relating to facing quality and appearance plus storage performance as demonstrated by Libessart et al. (2014) should be investigated and substantiated in the near future to better understand the type of new lubricant product family involved for market entry and acceptance.

For cost-benefit concrete production, the production line of mould oil should be located adjacent to concrete blocks manufacturing lines to allow for immediate and direct application of freshly made mould oil. Besides being environmentalfriendly and biodegradable, the formulated palm olein-based mould oil could offer less hazard, hassle and maintenance in the workplace, do away with irritating odour and flammable gas, provide compatible formed products quality, enhance the green image of the industry, etc. More importantly, the mould oil formulated is an ecofriendly biodegradable lubricant able to meet the HACCP system requirement widely enforced in today's good manufacturing industrial practices. Commercialisation efforts in recent years have shown that the palm olein-based mould oil is 20\%-30\% lower compared to market price. The findings are expected to demonstrate and guide the agricultural sector (e.g., oil palm industry players and farmers) in adopting resource diversification measure so as to utilise resource optimally and create value addition in order to support sustainable agriculture and a circular economy.

\section{CONCLUSION}

An eco-friendly biodegradable palm olein-based mould oil was formulated having $>60 \%$ ready biodegradability in aquatic environment within 23 days test period. Besides offering a decent workplace to workers, it performed satisfactorily as a mould release lubricant fulfilling every aspect of the specifications for mould oil used in concrete production sites besides ensuring that the production process and the finished concrete products conforming to higher standards and more stringent conditions and regulations. Both the finished concrete blocks and formwork showed smooth finishing without any underlying defect when applied with the 90:10 palm olein: tackifier optimum blend. Besides non-toxic in nature, its simple, straightforward and economical manufacturing process has driven it more appealing than the commercially available petroleum-based counterparts, as an emerging green product for not just the palm oil industry players but also other manufacturing industries gearing towards meeting the HACCP requirement. Future research should focus on quality of concrete surfaces to better understand the effects of concrete/oil/formwork interface phenomena.

\section{ACKNOWLEDGEMENT}

The authors thank the Director-General of MPOB for permission to publish this article. Thanks are also due to staff of the Energy and Environment Unit, MPOB for their technical assistances.

\section{REFERENCES}

Afifah, A N; Syahrullail, S; Azlee, N I W; Sidik, N A C; Yahya, W J and Rahim, E A (2019). Biolubricant production from palm stearin through enzymatic transesterification method. Biochem. Eng. J., 148: 178-184.

Annisa, A N and Widayat, W (2018). A review of bio-lubricant production from vegetable oils using esterification transesterification process. MATEC Web of Conferences 156: 06007. DOI:10.1051/ matecconf / 201815606007.

Argus Media (2021). Malaysia's Covid lockdown squeezes UCO supplies. https://view. argusmedia.com/APAC-EMD-2021-01-BIOArgus-Biofuels_01-News-Story-1.html, assessed on 18 May 2021.

Borugadda, V B and Goud, V V (2016). Improved thermo-oxidative stability of structurally modified 
waste cooking oil methyl esters for bio-lubricant application. J. Clean. Prod., 112(5): 4515-4524.

Bouharoun, S (2016). Characterization of the interface between fresh concrete and formwork. J. Civ. Eng. Manag., 22(1): 26-37. DOI: 10.3846/ 13923730.2014 .893912$.

Bouharoun, S; Vanhove, Y; Djelal, C; De Caro, $P$ and Dubois, I (2012). Interactions between superplasticizer and release agents at the concrete/formwork interface. Mater. Sci. Appl., 3: 384-389.

Cermak, S C; Biresaw, G and Isbell, T A (2008). Comparison of a new estolide oxidative stability package. J. Amer. Oil Chem. Soc., 85(9): 879-885. DOI: 10.1007 / s11746-008-1265-3.

Chan, C H; Tang, S W; Mohd, N K; Lim, W H; Yeong, S K and Idris, Z (2018). Tribological behavior of biolubricant base stocks and additives. Renew. Sustain. Energ. Rev., 93: 145-157.

Dandan, A and Samion, S (2017). Palm oil as an alternative lubricant oil: A brief review. The Colloquium, 11: 17-19.

Djelal, C; De Caro, P; Libessart, L; Dubois, I and Pebere, N (2008). Comprehension of demoulding mechanisms at the formwork/oil/ concrete interface. Mater. Struct., 41: 571-581.

EuropaLub (2015). EuropaLub Issue 1. Launch presentation. 2015. European Lubricants Statistical Service.

Farfan-Cabrera, L I; Gallardo-Hernández, E A; Gómez-Guarneros, M; Pérez-González, J and Godínez-Salcedo, J G (2020). Alteration of lubricity of Jatropha oil used as bio-lubricant for engines due to thermal ageing. Renew. Energ., 149: 11971204.

Fernandes, K V; Cavalcanti, E D C; Cipolatti, E P; Aguieiras, E C G; Pinto, M C C; Tavares, F A; Silva, P R da; Fernández-Lafuente, R; Arana-Peña, S; Pinto, J C; Assunção, C L B; Silva, J A C da and Freire, D M G (2021). Enzymatic synthesis of biolubricants from by-product of soybean oil processing catalyzed by different biocatalysts of Candida rugosa lipase. Catal. Today, 362: 122-129.

Fernandes, K V; Papadaki, A; Silva, J A C da; Fernandez-Lafuente, R; Koutinas, A A and Freire, D M G (2018). Enzymatic esterification of palm fattyacid distillate for the production of polyol esters with biolubricant properties. Ind. Crop. Prod., 116: 90-96.
Freedman, S (1975). Part I of a series on form release agents and form coatings, Publication \#C750084, The Aberdeen Group.

Gawrilow, I (2003). Palm oil usage in lubricants. Paper presented at the $3^{\text {rd }}$ Global Oils and Fats Business Forum USA. Interfacing with the Global Oils and Fats Business. 8 October 2003.

Gnanasekaran, D and Chavidi, V P (2018). Vegetable oil-based bio-lubricants and transformer fluids. Book Series: Materials Forming, Machining and Tribology. Springer Nature, Singapore. 155 pp.

Grand View Research (2016). Biolubricants market size to reach $\$ 2.92$ billion by 2024. https: / / www. grandviewresearch.com / press-release / biolubricants-market, accessed on 1 September 2016.

Hassan, M; Ani, F N and Syahrullail, S (2016). Tribological performance of refined, bleached and deodorised palm olein blends bio-lubricants. J. Oil Palm Res., 28(4): 510-519.

Ho, C K; McAuley, K B and Peppley, B A (2019). Biolubricants through renewable hydrocarbons: A perspective for new opportunities. Renew. Sust. Energ. Rev., 113: 109261.

Hussein, R Z K; Attia, N K; Fouad, M K and El Sheltawy, S T (2021). Experimental investigation and process simulation of biolubricant production from waste cooking oil. Biomass Bioenerg., 144: 105850.

Joseph, P V and Saxena, D (2017). Thermooxidatively improved environmental friendly base oils. STLE Atlanta. 21-25 May 2017.

KKM (2018). Kementerian Kesihatan Malaysia, Bahagian Keselamatan dan Kualiti Makanan, MeSTI. http: / / fsq. moh.gov.my/v6/xs/page.php?id=208 and http:/ / fsq.moh.gov.my/v6/xs/page.php?id=203, accessed on 17 May 2021.

Kheang, L S; May, C Y and Ngan, M A (2007). Residual oil from spent bleaching earth (SBE) for biodiesel and biolubricant applications. $M P O B$ Information Series No. 381.

Lafay, V S and Neltner, S L (2002). A biodegradable release agent increasing the life of concrete forms. US Patent: 2002172759 A1.

Liang, Y C; Loh, S K; Soon, L W and May, C Y (2016). Malaysian B5 implementation and its quality. J. Oil Palm Res., 28(3): 331-343.

Libessart, L; Djelal, C and de Caro, P (2014). Influence of the type of release oil on steel 
formwork corrosion and facing aesthetics. Constr. Build. Mater., 68: 391-401.

Lightcap, D V (1997). Vegetable oil-based sealing compositions for concrete. US Patent: 5647899 A.

Loh, S K; Chew, S M and Choo, Y M (2006). Oxidative stability and storage behavior of fatty acid methyl esters (FAME) derived from used palm oil. J. Amer. Oil Chem. Soc., 83: 947-952.

Loh, S K and Choo, Y M (2012). Influence of a lubricant auxiliary from palm oil methyl esters on the performance of palm olein-based fluid. J. Oil Palm Res., 24: 1388-1396.

Loh, S K; Muzzammil, N and Choo, Y M (2010). Palm-based mould oil for the steel/concrete industry. MPOB Information Series No. 521.

MPOB (2005). A compendium of test on palm oil products, palm kernel products, fatty acids, food related products and others. MPOB Test Methods (Aini, K; Siew, W L; Tan, Y A; Nor Aini, I; Tang, T S and Nuzul, A I eds.). MPOB, Bangi.

Mobarak, H M; Niza Mohamad, E; Masjuki, H H; Kalam, MA; Al Mahmud, KA H; Habibullah, M and Ashraful, AM (2014). The prospects of biolubricants as alternatives in automotive applications. Renew. Sust. Energ. Rev., 33: 34-43.

Nielsen, E (1985). Composition for release of a molded concrete body from the mold. PCT Int. Application: WO 8505066 A1.

Owuna, FJ;Dabai, MU; Sokoto, MA;Dangoggo, SM; Bagudo, B U; Birnin-Yauri, U A; Hassan, L G; Sada, I; Abubakar, A L and Jibrin, M S (2020). Chemical modification of vegetable oils for the production of biolubricants using trimethylolpropane: A review. Egypt. J. Pet., 29(1): 75-82.

Pindit, K; Thanapimmetha, A; Saisriyoot, M and Srinopakun, P (2021). Biolubricant basestocks synthesis using 5-step reaction from jatropha oil, soybean oil, and palm fatty acid distillate. Ind. Crop. Prod., 166: 113484.

Pirow, R; Blume, A; Hellwig, N; Herzler, M; Huhse, B; Hutzler, C; Pfaff, K; Thierse, H-J; Tralau, T; Vieth, B and Luch, A (2019). Mineral oil in food, cosmetic products, and in products regulated by other legislations. Crit. Rev. Toxicol., 49(9): 742-789. DOI: 10.1080/10408444.2019.1694862

Quinchia, L A; Delgado, M A; Franco, J M; Spikes, H A and Gallegos, C (2012). Low-temperature flow behaviour of vegetable oil-based lubricants. Ind. Crop. Prod., 37(1): 383-388.

Rac, A and Vencl, A (2008). Performance investigation of chain saw lubricants based on new sunflower oil (NSO). Proc. of the OTG-Symposium 2008. Wr. Neustadt, Austria. p. 249-257.

Rao, T V V L N; Rani, A M A; Awang, M; Baharom, M and Uemura, Y (2018). An overview of research on biolubricants in Malaysia and Japan for tribological applications. Jurnal Tribologi, 18: 40-57.

Research and Markets (2019). 2019 Report: Global lubricants market size is projected to reach USD188.0 billion by 2024 from USD164.3 billion in 2019, at a CAGR of 2.7\%. https: / / www. prnewswire. com/news-releases / 2019-report-global-lubricantsmarket-size-is-projected-to-reach-usd-188-0billion-by-2024-from-usd-164-3-billion-in-2019--ata-cagr-of-2-7-300951823.html, accessed on 18 May 2021.

Sahara Business Group (2021). Global lubricant demand.https: / / saharabizz.com/1279-2 /, accessed on 18 May 2021.

Shah, R; Woydt, M and Aragon, N (2020). Where are lubricants headed? Inform, 31(10): 12-15.

Singh, R; Lee, K T; Ooi, L C L; Low, E T L; Abdullah, M O; Sambanthamurthi, R and Azman, I (2021). An overview of the development of the oil palm industry and impact of the shell gene innovation as a quality control tool to improve productivity. J. Oil Palm Res. DOI: 10.21894/jopr.2021.0001.

Siti Afida, I; Razmah, G; Yeong, S K and Hazimah, A H (2015). Biodegradability of palm-based lubricants. J. Oil Palm Res., 27(4): 425-432.

Sönnichsen, N (2021). Global lubricant demand 20002019. https: / / www.statista.com/statistics/411616/ lubricants-demand-worldwide/\#statisticContainer, accessed on 18 May 2021.

Souza, M C de; Gonçalves, J F de S; Gonçalves, P C; Lutif, S Y S; Gomes, J de O (2019). Use of Jatropha and Moringa oils for lubricants: Metalworking fluids more environmental-friendly. Ind. Crop. Prod., 129: 594-603.

Srivastava, A and Sahai, P (2013). Vegetable oils as lube basestocks: A review. Afr. J. Biotechnol., 12(9): 880-891.

Sukirno and Farhandika, L (2020). Synthesis and characterisation of ethylene glycol ester from spent bleaching earth oil and ethylene glycol as 
hydraulic lubricants. AIP Conf. Proc., 2255: 060015. DOI: $10.1063 / 5.0021783$.

Syahrullail, S; Zubil, B M; Azwadi, C S N and Ridzuan, M J M (2011). Experimental evaluation of palm oil as lubricant in cold forward extrusion process. Int. J. Mech. Sci., 53(7): 549-555.

Theodori, D; Saft, R J; Krop, H and Van Broekhuizen, P (2004). Background document on development of criteria for the award of the European Eco-label to lubricants. https: / / ec.europa.eu/environment/ archives / ecolabel/pdf/lubricants/2ndbackdoc_1s tcriteria_def.pdf, accessed on 18 May 2021.

Wittich, L; Heck, S; Friesenhagen, L; Demmering, G; KomP, H-D and Koehler, M (1995). Emulsions for separating concrete forms. German Patent: 4400272 A1.
Woittiez, L S; Wijk, M T; Slingerland, M; Noordwijk, M and Giller, K E (2017). Yield gaps in oil palm: A quantitative review of contributing factors. Eur. J. Agron., 83: 57-77.

Woma, T Y; Lawal, S A; Abdulrahman, A S; Olutoye, M A and Ojapah, M M (2019). Vegetable oil based lubricants: Challenges and prospects. Tribol. Online, 14(2): 60-70.

Yi, R C (1996). A preparation of mold-releasing agent for concrete from industrial wastes. China Patent: 1129633.

Zhang, W; Ji, H; Song, Y; Ma, S; Xiong, W; Chen, C; Chen, B and Zhang, X (2020). Green preparation of branched biolubricant by chemically modifying waste cooking oil with lipase and ionic liquid. J. Clean. Prod., 274:122918. 